\title{
Correction to: Contributions of multiple climate hazards and overgrazing to the $2009 / 2010$ winter disaster in Mongolia
}

\section{Banzragch Nandintsetseg ${ }^{1,2}$ (D) $\cdot$ Masato Shinoda $^{1} \cdot$ Baasandai Erdenetsetseg $^{2}$}

Published online: 16 September 2020

(c) Springer Nature B.V. 2020

\section{Correction to: Nat Hazards (2018) 92: S109-S126 https://doi.org/10.1007/s11069-017-2954-8}

The article contains an error in its Data section. The author group would like all to note and acknowledge:

"Population and mortality data for livestock at the soum (district) level of Mongolia from 1945 to 2014 were obtained from the National Statistical Office (NSO) of Mongolia, as counted annually in December (NSO 2016)".

Should instead be:

"Population and mortality data for livestock at the soum (district) level for 2010 and at the country level for 1945-2014 were obtained from the National Statistical Office (NSO) of Mongolia, as counted annually in December (NSO 2016)".

Publisher's Note Springer Nature remains neutral with regard to jurisdictional claims in published maps and institutional affiliations.

The original article can be found online at https://doi.org/10.1007/s11069-017-2954-8.

Banzragch Nandintsetseg

nandiad98@gmail.com

1 Graduate School of Environmental Studies, Nagoya University, Nagoya, Japan

2 Information and Research Institute of Meteorology, Hydrology and Environment, Ulaanbaatar, Mongolia 